\title{
Helminths collected from the Indian Antelope,
}

\section{Antilope cervicapra.}

\author{
Par P. P. SINGH et B. P. PANDE
}

Five specimens of the black buck were autopsied, during the Academic Session 1961-62, by one of us (P.P.S.) to investigate its helminthic fauna and fourteen different forms recovered from various locations. The collection has an amphistomatous Trematode, one of the Anoplocephalid tapeworms of the genus Avitellina Gough, 1911, and the Nematodes are represented by four genera of Trichostrongyloids, two of Hookworms, one of the nodular worms, a pin-worm, a Trichurid and two Filariid genera. These have been studied from live specimens, stained and cleared preparations and sectioned material. The lesions, observed in some of these infestations, have likewise been studied from serially cut and stained sections and the main features of the pathogenic effects outlined. The present study is part of a research project to assess the incidence of the helminthic infestations amongst the wild Ruminants, particularly Cervidae, and to ascertain if the parasites were similar to or different from those of our domestic Ruminants.

Helminth parasites of this host have been investigated, from countries abroad, by Kreis (1935), Rewell (1948), Sloan (1951) and Jansen (1959). The only reference on this aspect in this country is on a crossbred deer from which a new species of a hookworm, Bunostomum bhawanagarensis (Ramanujachari and Alwar, 1951), has been described, from the duodenum and jejeunum.

\section{TREMATODA}

On one occasion, the rumen yielded a large number of specimens belonging to the Amphistome genus Gastrothylax Poirier, 1883, in which the various species are now assigned to three distinct genera: Gastrothylax Poirier, 1883, Carmyerius Stiles and Goldberger, 1910 and Fischoederius Stiles and Goldberger, 1910, mainly on the position of the uterus and the two testes. The specimens on account of the male end duct lying laterally and opposite to the terminal region of the uterus which, in front of the middle of the body, crosses over to the opposite side and in the presence of a well-developed pars-musculosa belong to Gastrothylax and the species is identified as G. crumenifer (Creplin, 1847) which is so far known to occur in cattle, buffalo, sheep and goat. Its incidence in Indian antelope is thus a first report. 


\section{CESTODA}

A heavy infestation with a representative of Avitellina was encountered in one of the antelopes examined. In addition to the adult worms, a large number of immature forms with their scolices lying embedded in the internal lining of the duodenum were observed, such sites exhibiting a somewhat nodulated character. Yamaguti (1959) has listed, under this genus, sixteen species some of these, on re-examination, may only

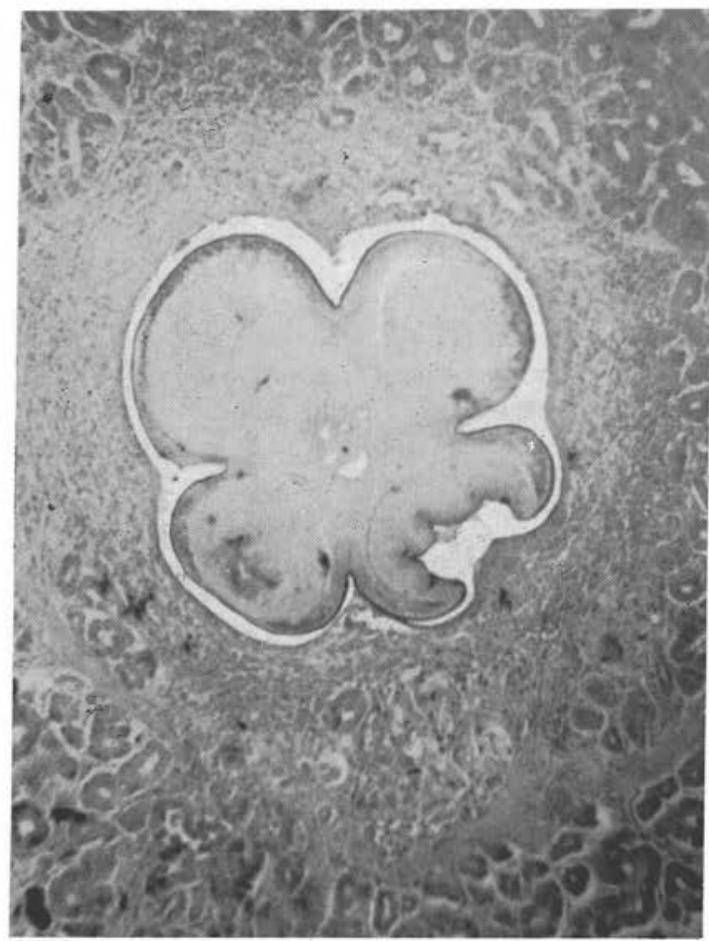

FIG. 1. - Microphotographs of a section of duodenum showing embedded scolex of the anoplocephalid tapewerm, cut transversely in the mucosa.

retain their validity. To distinguish the then known species of Avitellina, Bhalero (1936) gave a key which he had modified and enlarged from that given by Nagaty (1929). Wardle and McLeod (1952) also appended a similar key. A few of the allied species from antelopes were, however, separated under the genus Anootypus Woodland, 1928 , now with the only species $A$. edifortaineus Woodland, 1928 under it, on account of the presence of the ventral longitudinal excretory stem, the inner longitudinal muscles being single-layered and the cirrus-sac lying dorsal to the vagina. 
Relying on the characters utilized for identification of the different species of Avitellina, the specimens from the Indian antelope were found to belong to $A$. centripunctata Rivolta, 1874 - the genotype. Wardle and McLeod (1952) have listed sheep, goat, antelopes and buffalo as the hosts of A. centripunctata in Europe, South Asia and Africa but not in India (Itlics ours). Southwell (1930) had reported it from goat and camel. The recovery of $A$. centripunctata in this antelope shows that its occurrence may be more wide-spread.

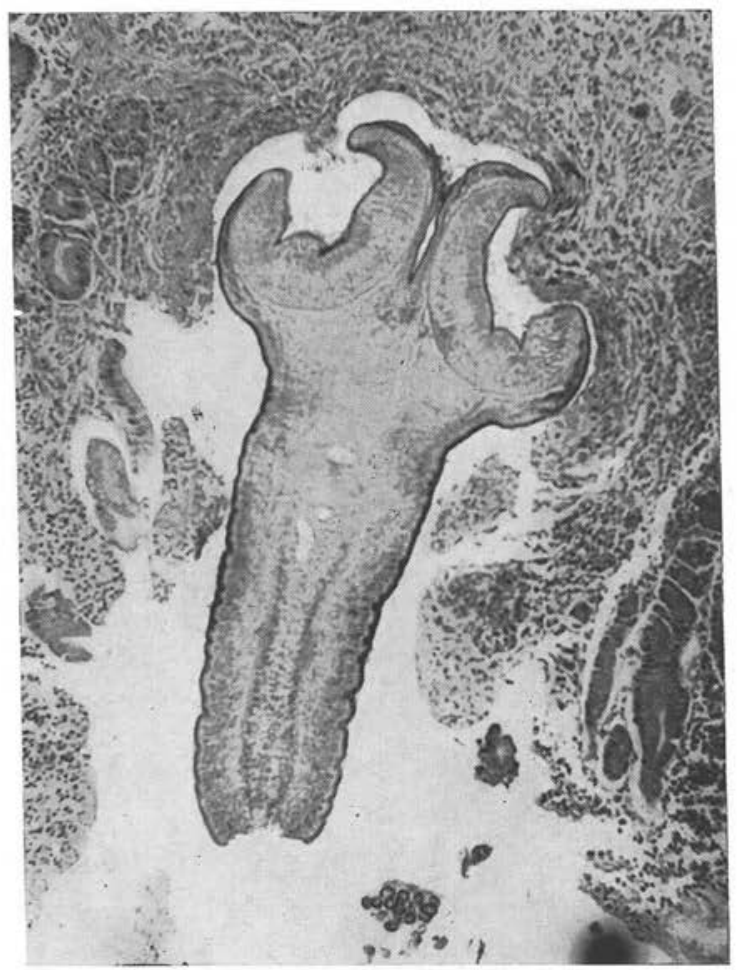

FIG. 2. - Microphotograph of another section of duodenum showing the scolex cut longitudinally and a coccidial patch on its right.

The study of the serially cut and stained sections of the apparent nodules, around the embedded scolices in the duodenal region, revealed a marked degree of pathological changes. The scolices, embedded deep in the mucosa, were as far as its submucosal region, patches of the tissues at such sites being drawn conspicuously inside the powerful suckers, (Fig. 1 and 2), the pathological changes consisting of superficial necrosis, denudation of the mucosal lining, hyperplasia of the glandular tissue with an increased 
development of the inter-glandular collagenous fibrous tissue. Prominent congestion of blood vessels of the sub-mucosal region and a thickening of the affected part which was invaded by lymphocytes, eosinophiles, macrophages and plasma cells were evident. During the study of this feature of the histopathology of Anoplocephalid tapeworm, some of the serial sections exhibited a concurrent Protozoan infection with an Eimerian parasite. The oocysts could not be recovered from the faecal samples and hence no data on sporulation, so essential for specific determination, could be obtained but the only stages identifiable were the female and male gamotocytes.

\section{NEMATODA}

\section{TRICHOSTRONGYLOIDS.}

The Trichostrongyloid Nematodes encountered belong to Trichostrongylus Looss, 1905, Ostertagia Ransom, 1907, Cooperia Ransom, 1907 and Haemonchus Cobb. 1898 (Family : Trichostrongylidae Leiper, 1912). The representative species of Cooperia were
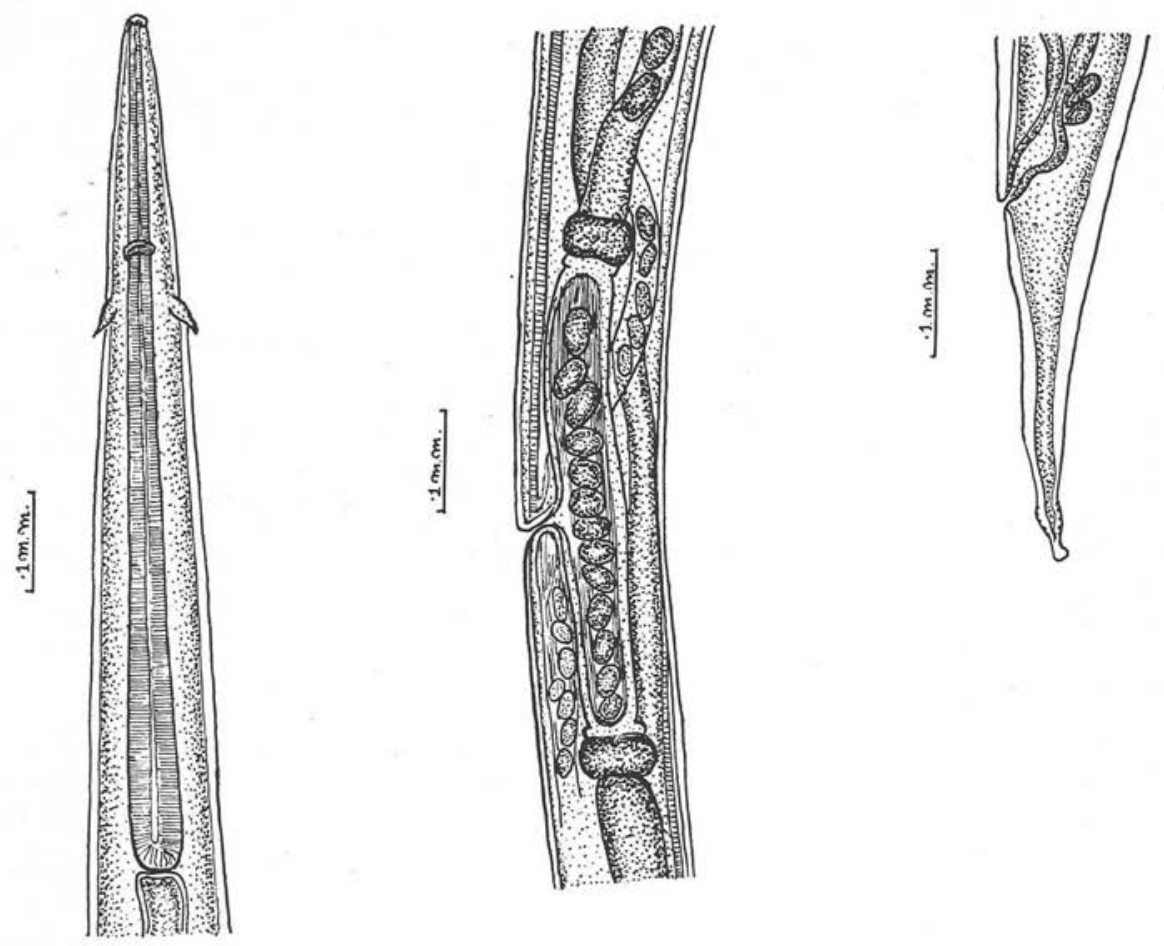

(Figs 3-7, Camera lucida drawings). Ostertiagia (Grosspiculagia) skrjabini.

Fig. 3. - Anterior end of the worm.

FIG. 4. - Genital opening of female worm.

Fig. 5. - Posterior end of female 
collected from duodenum, of Trichostrongylus from duodenum and abomasum while those of Haemonchus and Ostertagia from the abomasum. A few patches of the abomasal wall were histologically studied and the stained serial sections revealed the embedded juvenile and adult forms of Trichostrongylus (Fig. 8). Masses of eggs were also seen. The prominent pathological changes observed consisted of erosion of the mucosa, degenerative changes in the glandular cells and an infiltration of the leucocytic cells particularly the lymphocytes and plasma cells in the affected part.

\section{Trichostrongylus.}

From a perusal of the key given by Skrijabin et al $(1954,1960)$ for the species of this genus, the present specimens, on account of the dorsal ray being symmetrical and the spicules, of less than $0.20 \mathrm{~mm}$. in size, not being split at their hammer-shaped distal end which is more or less clearly demarcated from the rest of the spicule, come closer to the three species T. probolurus Railliet and Henry (1896) Looss, 1905, $T$. pietersei Leroux, 1932 and T. colubriformis (Giles, 1892). Because of the presence of a weakly-developed protuberance lying anterior to the leg-like distal extremity of the spicule and the anterio-lateral ray being widest of the lateral rays, the specimens are identified as belonging to $T$. columbriformis which Sloan (1951) and Jansen (1959) recorded from this host.

Mixed with specimens of $T$. columbriformis were found three male worms of another species with different features of the spicules and the externo-dorsal ray. These specimens measured 4-5 $\mathrm{mm}$. in length and $0.06-0.07 \mathrm{~mm}$. in maximum breadth with oesophagus $0.60-0.65 \mathrm{~mm}$. long, nerve ring $0.15 \mathrm{~mm}$. and excretory pore $0.13 \mathrm{~mm}$. distant respectively from the anterior extremity. Spicules nearly unequal, (smaller $0.09-0.10 \mathrm{~mm}$. long and larger $0.11-0.12 \mathrm{~mm}$. long) with two inwardly directed projections lying behind its middle, the inner one being longer. Gubernaculum elongated, 0.05-0.06 mm. long and 0.006-0.008 mm. in breadth. Externodorsal ray, in one of the specimens, exhibiting behind its tip four small diverticulae on each side. These worms belong to $T$. axei (Cobbold, 1879) Railliet et Henry, 1909, which has also been recorded by Sloan (1951) and Jansen (1959) from this host species.

\section{Haemonchus.}

Baylis and Daubney (1922) described, from the axis deer (Cervus axis), a new species of this genus, $H$. cervinus, [later listed by Baylis (1936) as a synonym of H. contortus (Rudolphi, 1803) Cobb, 1898] which Skrjabin et al recognised as a valid form. The vulva was believed to be with no hanging lip-like flap or projection like the one seen in $H$. contortus. Full details of the bursa were not available to the joint authors and this probably accounts for the merging of the species under $H$. contortus by Baylis (1936). Sloan (1951) had recorded $H$. contortus from Antilope cervicapra.

A large number of specimens belonging to Haemonchus were collected from all the five animals examined. These worms, because of the equal spicules measuring less than $0.60 \mathrm{~mm}$. in length, not being split distally, with no sharp spines on their central parts, with the barb at the distal end of the left spicule lying at a distance of 
less than $0.09 \mathrm{~mm}$. from the tip and gubernaculum being more than $0.16 \mathrm{~mm}$. in length show close affinites with $H$. contortus and $H$. mitchelli Leroux, 1929 than with the other known species in accordance with the key given by Skrjabin et al for distinguishing

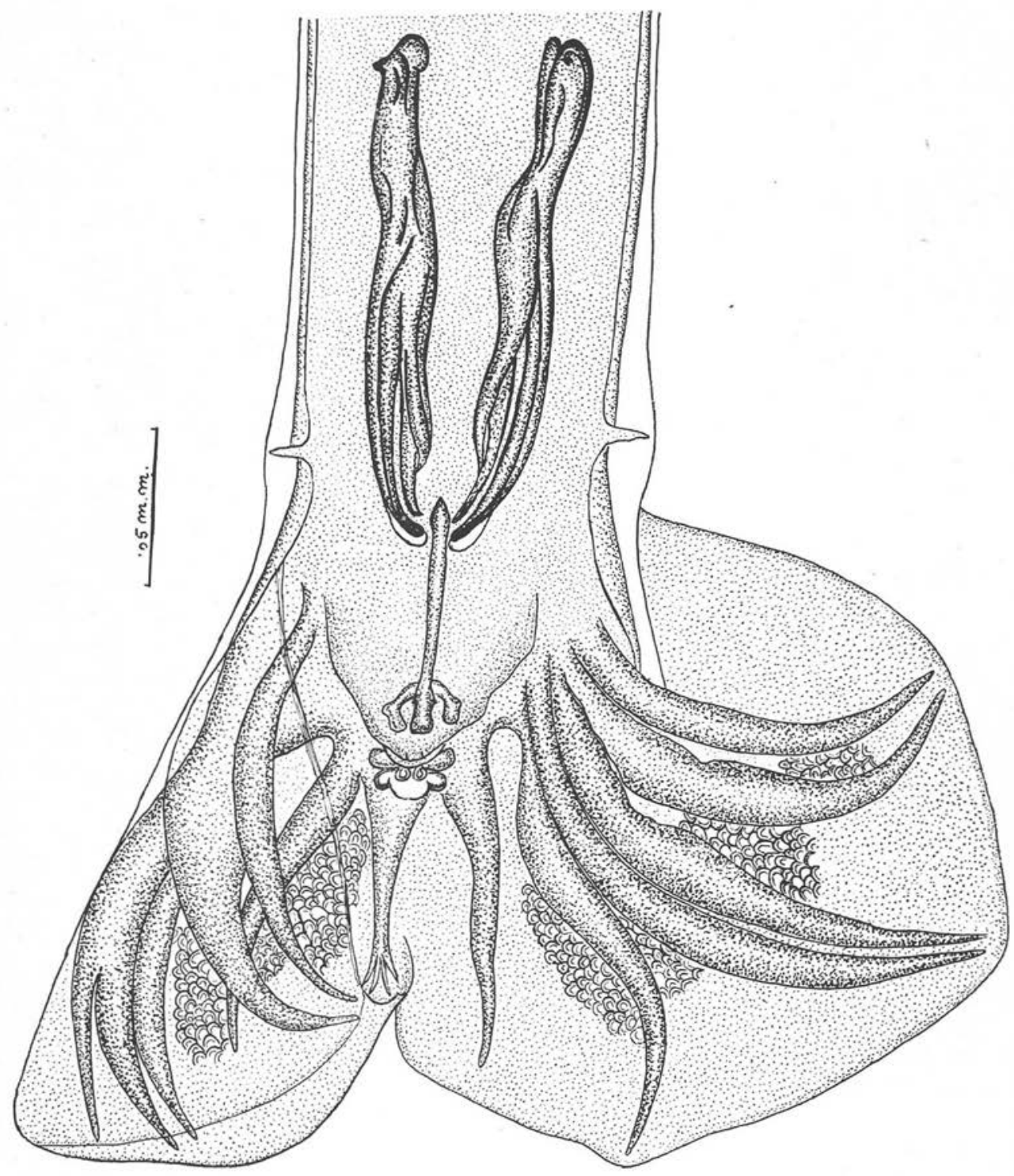

FIG. 6. - Bursa of male worm. 
the various species of Haemonchus. On the basis of the characters stressed by Baylis (1936) particularly on account of the position of the barbs of both the left and right spicules at $0.01-0.02 \mathrm{~mm}$. and $0.028-0.04 \mathrm{~mm}$. respectively, this form was identified as belonging to $H$. contortus. Skrjabin et al, however, give the position of these barbs on the left and right as $0.023-0.025 \mathrm{~mm}$. and $0.048-0.058 \mathrm{~mm}$. respectively, a disparity resulting probably from the measurements getting intermixed.

\section{Cooperia.}

Two male and one female specimens were once collected from the animals examined. A large number of species of this genus have been reported from abomasum

Fig. 7. - The two spicules with the club-shaped gubernaculum

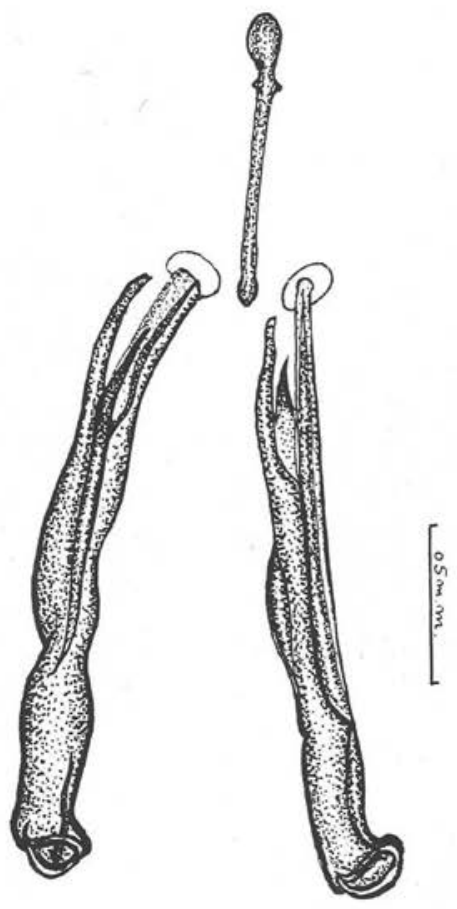

and small intestine of Cervidae. Following the key given by Skrjabin et al the specimens, on account of the lateral branching of the dorsal ray at the level of bifurcation, resemble such species as C. yoshidai Mönnig, 1939, C. laterouniformis Chen, 1937, C. punctata (Linstow, 1906) Ransom, 1907 and C. africana Mönnig, 1932. Because the two lateral processes of the dorsal ray are bent sharply ventrally in a characteristic manner, the specimens come closer to C. laterouniformis as in C. punctata there is no such bending of the processes. Accordingly, the specimens are identified as belonging to $C$. laterouniformis which has so far been encountered in local buffalo. 


\section{Ostertagia.}

This genus, according to Skrjabin et al has the three sub genera: Ostertagia (Ransom, 1907), Costarcuata Schulz and Kadenatsii, 1950 and Grosspiculagia Orloff, 1933 which are separated on the characters of the dorsal ray and the distal branching of the spicules. In Costarcuata, the dorsal ray has a short trunk and its two long branches, nearly 3 or 4 times the length of the main stem and bent in an arc-like manner and the spicule distally has three branches. In the two other subgenera, the dorsal ray is without the two large branches bending in an arc-shaped form. The sub-genus Ostertagia is characterized by a dorsal ray of medium length and split into

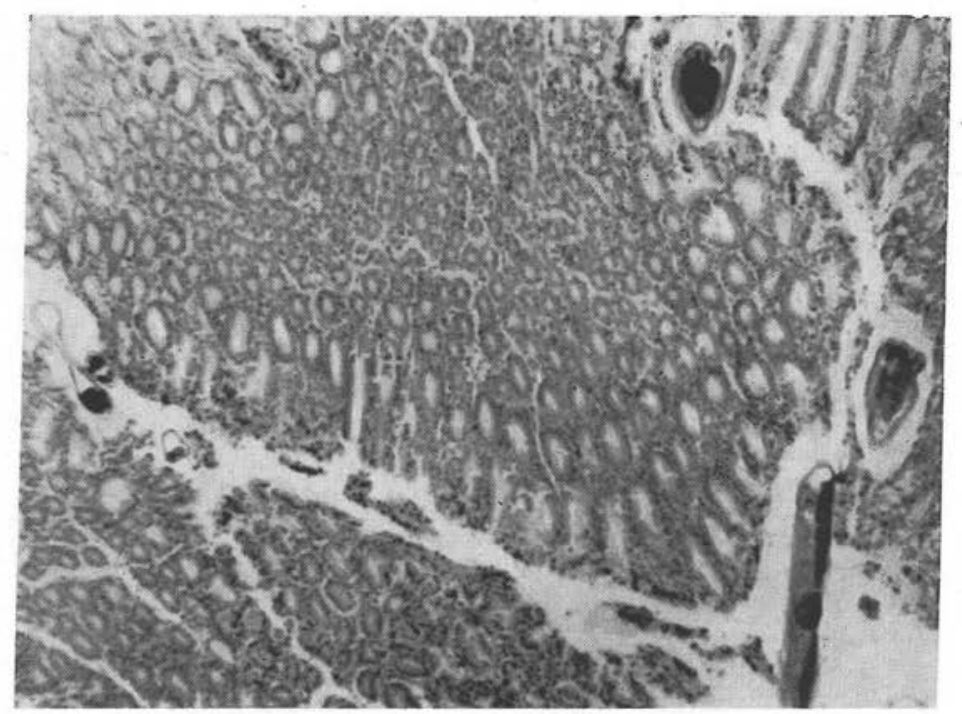

FIG. 8. - Microphotograph of a section of abomasum showing Trichostrongylus sp. female embedded deep inside the mucosa.

branches with its trunk nearly twice the length of the branches and the spicules have distally thin branches while in Grosspiculagia lateral lobes are separated only slightly from shortened dorsal lobe or may not be separated at all, the dorsal ray is more elongated and two of the branches of the spicules at distal ends are thick and more powerful.

The only reference to the occurrence of Ostertagia infection in Antilope cervicapra is that of Sloan (1951) who reported the two species: O. circumcincta (Stadelmann, 1894) Ransom, 1907 and $O$. trifurcata Ransom, 1907 which in view of the recognition of the three subgenera would be $O$. (O.) circumcincta (Stadelmann, 1894) Ransom, 1907 and $O$. (O.) trifurcata Ransom, 1907. 
About ten male and fifteen female specimens belonging to this genus were collected from the abomasum during the present study. The worms had tapering ends with prominent cervical papillae situated a little distance behind the nerve ring (Fig. 3).

MALE : Specimens measure 7.0-9.0 mm. in length and 0.12-0.14 mm. in maximum breadth. Cervical papillae and nerve ring lie at $0.22-0.25 \mathrm{~mm}$. and $0.23-0.26 \mathrm{~mm}$. distance respectively behind the anterior end. Oesophagus is $0.75-0.88 \mathrm{~mm}$. long. Prebursal papillae present. Bursa (Fig. 6), with large lateral lobes and a very small dorsal lobe, lined internally with prominent cuticular bosses. Ventral rays, throughout their length, quite apart, anterio-ventral being thinner. Lateral rays with the anterioand medio-laterals parallel, posterio-lateral being disposed towards the externo-dorsal arising from the base of the dorsal ray which, with a broader base, divides twice at its tipinner branches being longer than outer ones. Prominent genital cone with two pairs of coiled processes near its tip - external pair being longer than the internal one. Spicules equal, $0.16-0.18 \mathrm{~mm}$. in length, with a cap-like structure proximally and carrying, behind the second third of its length, three processes - one with a pointed tip being the shortest ; the second, though longer and reaching as far as the tip of the spicule, likewise has a pointed tip ; the third, with a curved tip, is capped by an inflation (Fig. 6). The gubernaculum, 0.081-0.09 mm. long, pointed proximally but distally somewhat swollen giving it a more or less club-shapped appearance (Fig. 6 and 7).

Female : Specimens 9.2-10.1 mm. in length with a maximum breadth of 0.15 $0.16 \mathrm{~mm}$. Oesophagus $0.76-0.83 \mathrm{~mm}$. long. Nerve ring and cervical papillae at $0.23-0.28 \mathrm{~mm}$. and $0.27-0.30 \mathrm{~mm}$. distance respectively behind the anterior end. Tail, 0.14-0.20 mm. long, slightly swollen behind its tip with four/five serrations in this zone (Fig. 5). Vulva, at 1.50-1.75 mm. distance in front of the posterior extremity, leading through a small vagina into the combined ovejectors which, with sphincters, measure 0.42-0.57 mm. in length (Fig. 4). The intrauterine eggs measure 0.034-0.041 $\times$ 0.017-0.020 $\mu$ in size.

The present material, on account of the lateral lobes of bursa being slightly separate from the elongated dorsal lobe, the dorsal ray being elongated and bifurcated, the stout spicules split into three processes of which two are more massive and the presence of a gubernaculum belongs to the subgenus Grosspiculagia which, according to Skrjabin et al, includes the seven species: O. (G.) petrovi Puschmenkov, 1937 ; O. (G.) aegagri Grigorian, 1951 ; O. (G.) volgaensis Tomskich, 1938 ; O. (G.) lyrata Sjoberg, 1926 ; O. (G.) occidentalis Ransom, 1907 ; O. (G.) nemorhaedi Schulz and Kadenatsii, 1950 ; O. (G.) arctica Mitskevitch 1929 ; O. (G.) lasensis Assadov, 1953. These are separated on the size of the spicules, length of the gubernaculum and its shape, character of the proximal end of the spicule, splitting of the dorsal ray and its branches and the nature of the processes, whether present at the middle or behind the middle of the spicules. As the spicules in our material with a length of more than $0.100 \mathrm{~mm}$. have no complex configuration at their proximal ends and the dorsal ray branches at its distal third or quarter, these specimens show some resemblance to $O$. $(G$.) occidentalis, known from sheep, goat and deer but differ from it on account of the smaller size of the spicules 
which divide behind their middle, the different shape of the smaller sized gubernaculum and the terminal branching of the dorsal ray - the four branches arising together near its tip with the two inner ones being longer. In the size of its spicule and the gubernaculum and in the origin of the processes near the distal third of the spicules, the specimens also show a resemblance to $O$. $(G$.) arctica, known from reindeer, which can be distinguished because the spicules are $0.179-0.209 \mathrm{~mm}$. long and the gubernaculum $0.078-0.082 \mathrm{~mm}$. in length. A significant difference, however, is observed on a comparison of the dorsal ray which in $O$. (G.) arctica divides in its last quarter, the

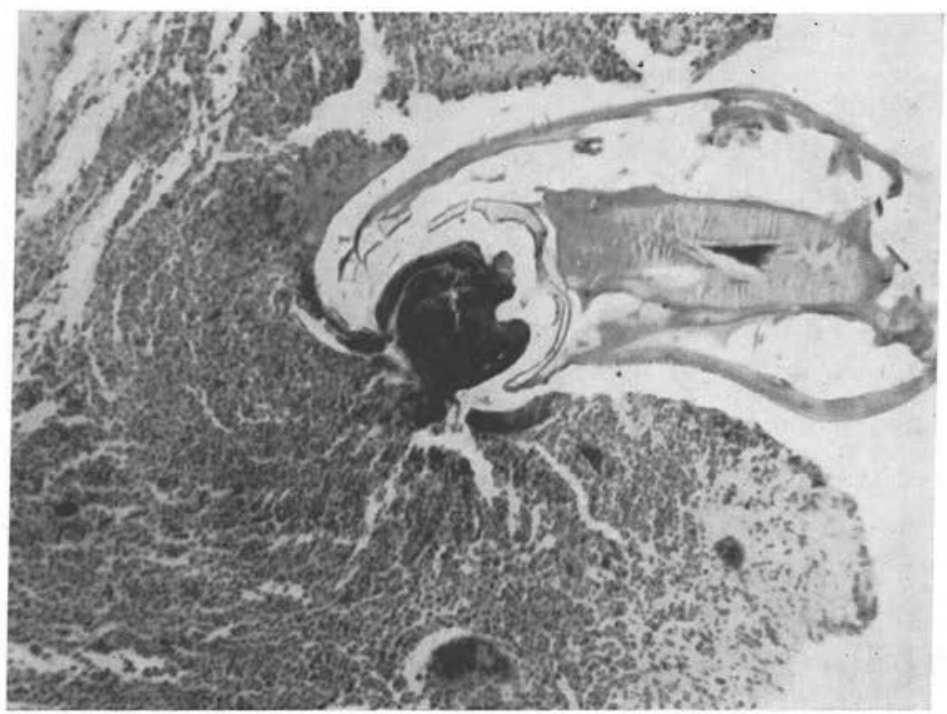

Fig. 9. - Microphotograph of a section of small intestine showing the attached anterior end of $B$. trigonocephalum. Note the mucosal patch drawn inside the buccal capsule and intense cellular changes.

two branches diverging widely and each branch, near its middle, has small lateral offshoots and terminally gives off a slightly longer median branch. $O$. (G.) lasensis (described from male specimen alone from the abomasum of a roe) has an entirely different configuration of its spicules and also differs on account of the shape of its gubernaculum. In view of these differences, it is proposed to assign the specimens, tentatively, to a new species designated as $O$. (G.) skrjabini after the eminent Russian helminthologist. (The type specimens deposited in Departmental Collection).

\section{HOOK-WORMS.}

The hook worms collected belong to the two species Bunostomum trigonocephalum (Rudolphi, 1808) Railliet, 1902 and Gaigeria pachyscelis Railliet and Henry, 1901. 

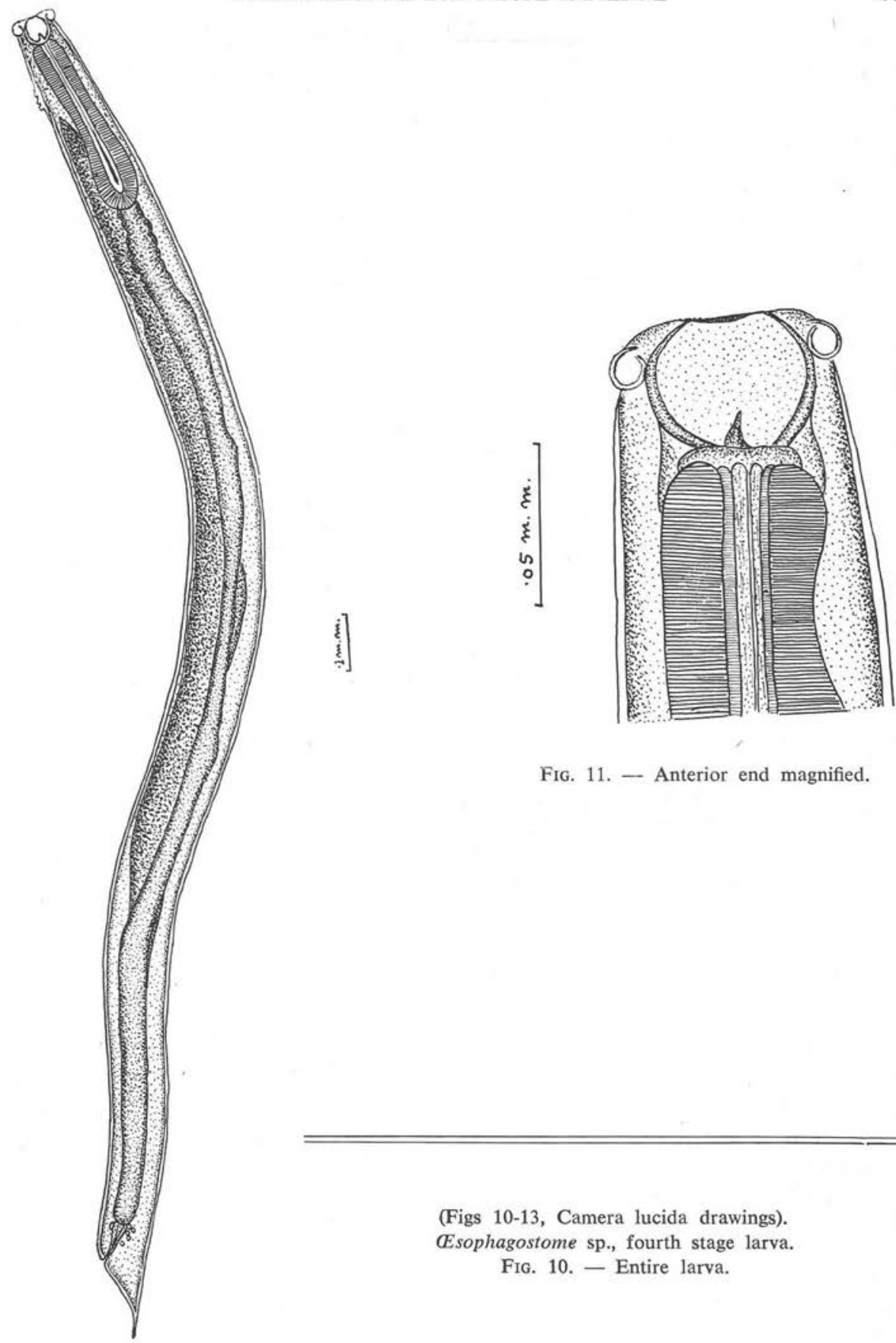

FIG. 11. - Anterior end magnified.

(Figs 10-13, Camera lucida drawings). Esophagostome sp., fourth stage larva. FIg. 10. - Entire larva. 
The former is known to be a common parasite of sheep, goat, ox and other Ruminants including Cervidae, while the latter is of common occurrence in sheep, goat and buffalo. Reports available on the Helminths of Antelope cervicapra do not indicate their incidence. The specimens available agree in all details with the descriptions of these forms.

In order to assess the extent of damage inflicted to the lining of the small intestine (jejunum and ileum), a histological study of the patches with specimens of $B$. trigonocephalum attached was undertaken and the histopathological changes in and around the tissue studied. The worms, with their anterior ends deeply embedded into the mucosa and reaching as far below as the muscularis mucosae, had large mucosal plugs inside the capacious buccal capsules (Fig. 9). At such sites, a complete destruction of the villi had resulted and the whole area was haemorrhagic with severe mechanical damage. In addition, the marked cellular reaction revealed an increased number of lymphocytes and eosinophilic cells and the blood capillaries were congested and enlarged.

\section{NODULAR WORM.}

The species of the genus Oesophagostomum Molin, 1861 known from some of the Cervidae, as listed by Baylis (1936), are: Oesophagostomum venulosum (Rudolphi, 1809) Railliet, 1885, O. indicum Maplestone, 1931 and O. traguli Maplestone, 1932. According to Lapage (1956), O. columbianum (Curtice, 1890) Stossich, 1899 occurs in the colon of sheep, goats and a number of wild antelopes. So far, the occurrence of Oesophagostomum in Antilope cervicapra does not seem to have been recorded.

On one occasion, the caecal part of the large intestine exhibited a number of nodules resembling those encountered in the "pimply gut 》 of the domestic Ruminants. These on teasing yielded juvenile fourth stage forms, briefly described below.

Larvae (Fig. 10), 2.0-2.31 mm. long and 0.16-0.18 mm. in maximum thickness. Buccal capsule cupshaped, $0.04 \mathrm{~mm}$. in diameter, with a small tooth projecting from its base into the cavity (Fig. 11). Oesophagus club-shaped, $0.31 \mathrm{~mm}$. long. Cervical groove near middle of the oesophagus, $0.16 \mathrm{~mm}$. distant from the anterior extremity. Tail tapering, 0.09-0.16 mm. long. [The genital rudiments and the character of the tail length indicate the future sex of the larvae. Those destined to become males are with a shorter tail ending bluntly, spicular structures apparent on the two sides of the junction between intestine and rectum and show rudiments of coiled gonad (Fig. 12). In larvae to develop into females a longer tail with a pointed tip and rudiments of ovijector as a slightly swollen structure, on one side of the intestinal end and continuing as a coiled tube of cellular character — the developing uterus, are seen (Fig. 13)].

In the absence of the adult specimens in the present collection, a specific determination is not possible but Antilope cervicapra has been found to harbour an oesophagostomal infection.

Histological study of these nodules, from serially cut and stained sections, revealed the juvenile stage inside and considerable area of the submucosa was involved (Fig. 14). The nodule was caseated at its centre with numerous degenerated nuclei. The larvae, in their buccal capsules, had a cellular mass of the tissue (Fig. 15). A wall of fibrous 
elements had developed around and nodule internally exhibited macrophages, lymphocytes and some neutrophiles intermixed with collagenous fibres. From the pressure of the greatly sized nodules, the mucosal lining of the caecum was much rarified at such places.

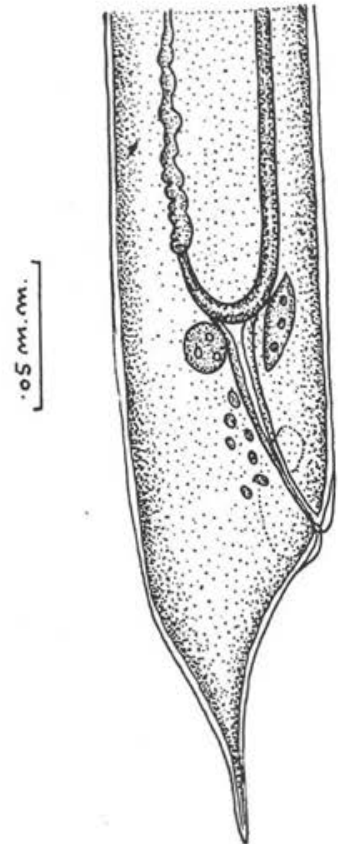

Fig. 12. - Posterior extremity of a future male

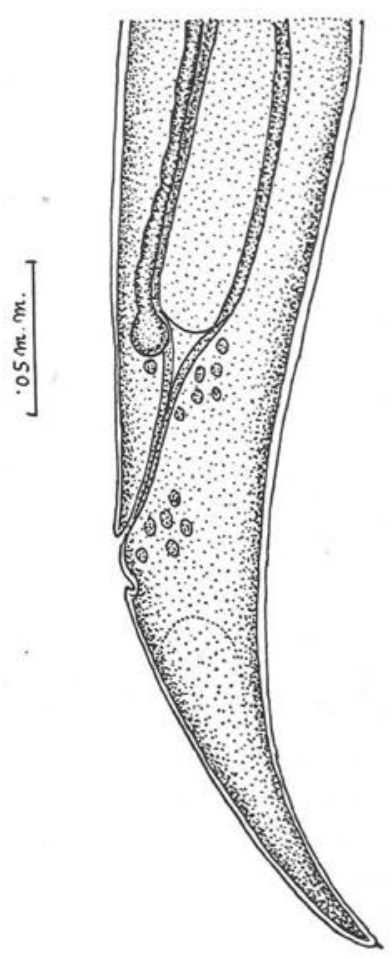

Fig. 13. - Posterior extremity of a future female

\section{PIN WORM.}

One female specimen of an Oxyurid worm, collected from the caecum of one of the animals, had eggs filling up its uterus. It belongs to the genus Skrjabinema Vereschagin, 1926. Olsen (1949) has described the male of the deer pinworm, S. parva Dickman, 1942. In 1950, Olsen and Tolman described the male of the species which was obtained from the mule deer and gave an emended diagnosis of the genus and a key for its species. Relying on this key, the female specimen is assigned to the species, S. ovis Skrjabin, 1915 . The specimen measures $7.25 \mathrm{~mm}$. in length and $0.53 \mathrm{~mm}$. in maximum breadth. Its oesophagus is $0.53 \mathrm{~mm}$. long and the posterior bulb $0.15 \mathrm{~mm}$. 
in size. The tail measures $0.77 \mathrm{~mm}$. in length. The vulva is situated at $2.11 \mathrm{~mm}$. distance behind the mouth opening. The eggs are 47.6-49.3 $\times 27.2 \mu$ in size.

S. ovis, reported by Bhatia and Pande (1961) in sheep, has been found in this antelope.

\section{TRICHURIS.}

The two species of this genus that have been reported from Antilope cervicapra are : T. cervicapra Kreis, 1935 and T. ovis (Abildgard, 1795) Smith, 1903. Two female Trichurids, recovered from the large intestine of one of the antelopes examined, were found to belong to $T$. ovis, which is characterised by a relatively long and slender

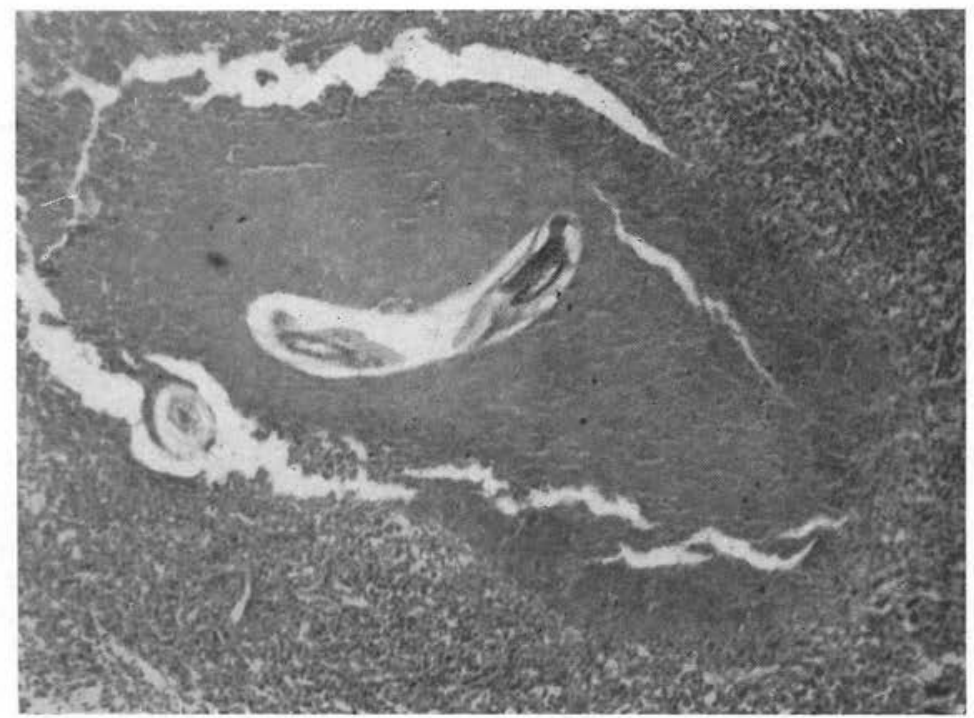

FIG. 14. - Microphotograph of a section of caecum showing an œsophagotosme larva cut inside the nodule

vagina pursuing a regularly wavy course with its muscular wall gradually widening posteriorly. This species occurs in local sheep, goat and other Ruminants. The Worms measure $50-55 \mathrm{~mm}$. in length and $0.68-0.69 \mathrm{~mm}$. in maximum thickness. The intrauterine brownish and barrel-shaped eggs, with transparent plugs at their poles, measure $0.053-0.076 \times 0.030-0.038 \mathrm{~mm}$. in size, including plugs.

\section{SETARIID WORMS.}

The Setariid worms, collected from the peritonial cavity of one of the five antelopes available for examination, were cleared and on study found to belong to two distinct 
genera : Setaria Viborg, 1795 and Papillosetaria Vevers, 1923. The former is represented by one male and three female specimens and the latter by a single female worm. The two genera, resembling in their general form, can be distinguished on account of the presence in Setaria of a typical circumoral ring which is absent in Papillosetaria in which the paired lateral lips are lined by thickened cuticle and the body cuticle, except at the ends, carries irregularly scattered bosses.

\section{Setaria.}

According to Baylis (1939), Setaria cervi (Rudolphi, 1819) Baylis, 1936 is of wide occurrence both in Bovidae and Cervidae which include antelopes, deer and moose.

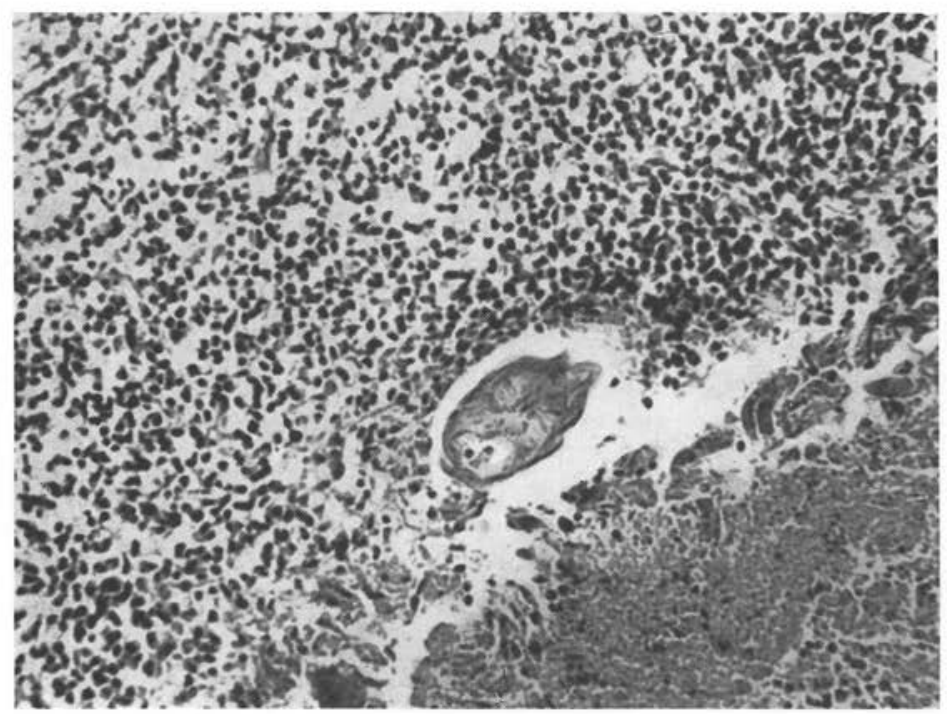

FIG. 15. - Microphotograph of a section of an esophagostomal nodule showing the cut anterior end of the larva.

In a recent revision of this genus, Yeh (1959) has separated some of the species of Setaria, under his new genus, Artionema, which in Cervidae has the three species: A. altaica Raevskaya, 1928 Yeh, 1959, A. hertwichi Yeh, 1959 and A. tundra (Isaichikov and Raevskaya, 1928) Yeh, 1959. Amongst these, our specimens, which are slightly smaller, on account of the head carrying only the dosal and ventral elevations and the female with small caudal appendages and the tail ending in a terminal knob, resemble $A$. hartwichi. There is also the resemblance seen in the character and the size of the spicules, number and arrangement of the caudal papillae, and the distance of the caudal appendages from the caudal extremity. The only difference, however, is with regard to the terminal knob in the female, which as described by Yeh, is slightly elongated while in our specimens it is rounded. 


\section{Papillosetaria.}

To its genotype, P. traguli Vevers, 1922, a second species, P. viversi Maplestone, 1931 was added by Maplestone from Tragulus javanicus (Zoological gardens, Calcutta). The description of the latter, as given by Baylis (1939), has been compared with the

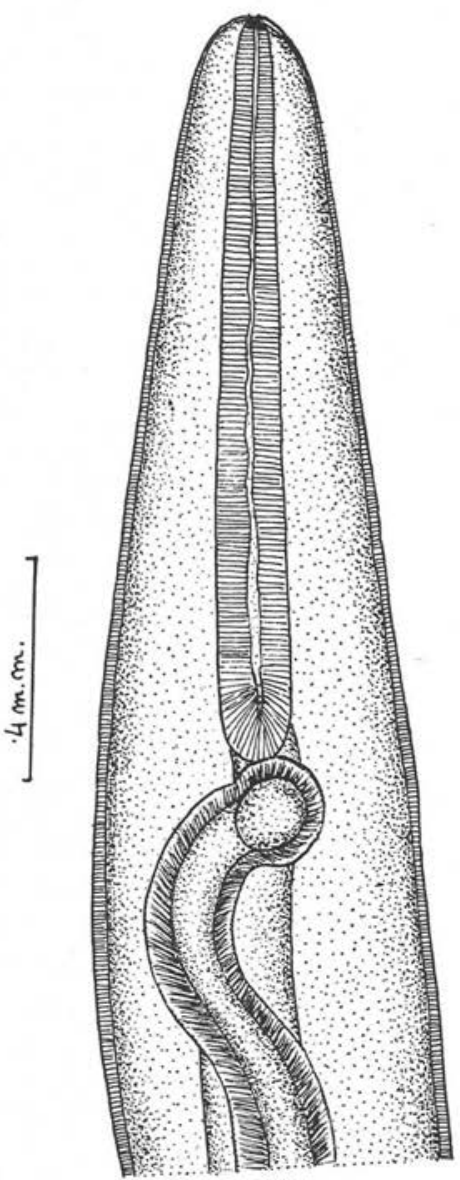

FIg. 16-18. - Camera lucida drawings. P. verversi

Fig. 16. - Anterior end

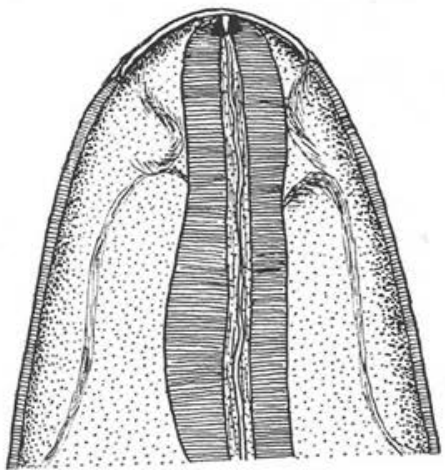

FIG. 17. - Anterior end, under high power

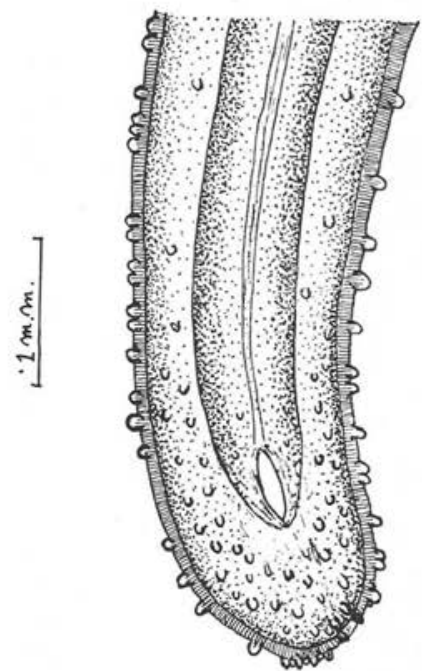

Fig. 18. - Posterior end of the female worm with a large number of cuticular bosses/papillae.

only one female worm, recovered from one of the antelopes and the specimen is tentatively identified as belonging to $P$. veversi. Discovery of male specimens and more female worms, at a later stage, can only determine its actual status. 
The female specimen, measuring $150 \mathrm{~mm}$. in length and $0.63 \mathrm{~mm}$. in maximum breadth, has a somewhat tapering anterior and a blunt posterior extremity. The cuticle is provided with irregularly distributed cuticular prominences/bosses which start from about $10 \mathrm{~mm}$. behind the anterior extremity and extend upto the caudal end which, however, shows a greater concentration. The muscular layers of the worm appeared to be quite thick as treatment with even lactophenol did not bring out clearly the details of the internal structures. The mouth end, without a peri-buccal ring and the other associated structures, shows two cuticular thickenings (Fig. 16 and 17). The oesophagus is in two parts, the anterior measuring $1.2 \mathrm{~mm}$. in length. The nerve ring lies at $0.27 \mathrm{~mm}$. distance from the anterior end. The vulva, situated at $1.20 \mathrm{~mm}$. distance behind the oral opening, leads into a prominent muscular sphincter of nearly rounded shape. The tail measures $0.26 \mathrm{~mm}$. in length. The caudal extremity is studded with bosses/papillae (Fig. 18).

In its size and the distribution of the cuticular bosses, the specimen agrees with the necessary details given by Maplestone for the females of $P$. veversi. The only difference, however, relates to the absence in our specimen of the definite pair of caudal papillae mentioned by Maplestone.

\section{Summary}

The blackbuck (Indian antelope), Antilope cervicapra, has been found to harbour fourteen distinct species of Helminths of which Trichostrongylus columbriformis, T. axei, Haemonchus contortus, Trichuris cervicapra and $T$. ovis alone seem to have so far been reported. Thus, the new records are for Gastrothylax crumenifer, Avitellina centripunctata, Cooperia laterouniformis, Bunostomum trigonocephalum, Gaigeria pachyscelis, Oesophagostomum sp., Skrjabinema ovis, Artionema hartwichi, Papillosetaria veversi and a species of Ostertagia, O. (Grosspiculagia) described and designated tentatively as $O$. (G.) skrjabini, n. sp. Besides, the lesions associated with immature Anoplocephalid scolices exhibiting a concurrent Eimerian infection, Trichostrongyle infection of abomasum, hook worm infestation and oesophagostomal nodules of the caecum have also been dealt with briefly.

\section{Acknowledgements.}

Thanks are due to the U.S. Department of Agriculture, Washington for making available the translation of the Russian Volume on Trichostrongylids of animals and man, to the Principal of the College for the facilities provided and to the Professor of Zoology, Agra College, Agra, for giving the Zoological name of the host animal.

\section{Résumé}

L'antilope indienne, Antilope cervicapra (5 spécimens autopsiés), a été trouvée porteuse de 14 espèces différentes d'Helminthes, parmi lesquelles seules avaient été signalées jusqu'alors : Trichostrongylus columbriformis, T. axei, Haemonchus contortus, 
Trichuris cervicapra et $T$. ovis. Les espèces non encore mentionnées chez ces Mammifères sont Gastrothylax crumenifer, Avitellina centripunctata, Cooperia laterouniformis, Bunostomum trigonocephalum, Gaigeria pachyscelis, Esophagostomum sp., Skrjabinema ovis, Artionema hartwichi, Papillosetaria veversi; une espèce d'Ostertagia (Grosspiculagia), présumée nouvelle, a été décrite sous le nom de $O$. (G.) skrjabini n. sp. Les lésions imputables à la pénétration de scolex de nombreuses formes immatures d'Anoplocephalidés dans la paroi interne du duodénum présentaient une infection associée, de type Eimeria. En outre, ont été observés des infections à Trichostrongylus et à Ankylostomes, ainsi que des nodules cæcaux à Esophagostomum.

\section{Références}

Baylis, H.-A. (1936). - The fauna of British India, including Ceylon and Burma. Nematoda, Vol. I, Taylor and Francis, London, $408 \mathrm{pp}$.

- (1939). - The fauna of British India, including Ceylon and Burma. Nematoda, Vol. II, Taylor and Francis, London, 274 pp.

- and Daubney, R. (1922). - Report on the parasitic Nematodes in the collection of the Zoological Survey of India. Mem. Ind. Mus., Calcutta., vII, 263-347.

Bhalerao, G.-D. (1936). - On some representatives of the Cestode genus Avitellina from India. J. Helminth. 14 (3): 141-162.

Bhatia, B.-B. and PANDE, B.-P. (1961). - On the common helminthic infections of the large intestine in Indian Sheep with remarks on two of the pathogenic species. Indian J. Helminth. Ë3, 1-22.

JANSEN, J.-Jr. (1959). - Auchenia glama and Antilope cervicapra, new hosts for some Trichostrongylidae. J. Parasitol. 45 (5), 509.

KreIs, H.-A. (1935). - Beitrâge zur Kenntnis parasitischer Nematoden. 1. Ein. neuer parasitischer Nematodes aus der Hirschziegenantilope, Antilope cervicapra L.: Trichuris cervicaprae, $\mathrm{n}$. sp. (Trichurinae Ransom, 1911; Trichuridae Ransom, 1911; Trichuridae Railliet, 1915; Trichuroidea Railliet, 1916). Verhandlungen der Naturforschenden Gesellschaft in Basel. XLVI, 59-65 (Helm. Abs. 4 (2) Abst. No. 182 a).

LAPAGE, G. (1956). - Mönnig's Veterinary Helminthology and Entomology Baillière, Tindall et Cox. London, 4th edition, $511 \mathrm{pp.}$

Negaty, H.-F. (1929). - An account of the anatomy of certain Cestodes belonging to the genera Stilesia and Avitellina. Ann. Trop. Med. Parasit. $23: 349-380$. (cited by Bhalerao, 1936).

OLSEN, O.-W. (1949). - Description of the male of the deer pinworm, Skrjabinema parva. J. Colorado-Wyoming Academy of Science. 4 (1), 64. (Helm. Abst. 18 (5) Abst. No. 665 b).

- $\quad$ and Tolman, C.-D. (1950). - Description of the male of the pinworm, Skrjabinema parva Dikmans, 1942 (Nematoda: Oxyuroidea) from deer, with an emendation of the genus. J. Parasitol. 36 (5) : 411-415.

RAmanUjachari, G. and AlWAR, V.-S. (1951) - Bunostomum bhavanagarensis n. sp. Indian Vet. J. 27 (4), 239-243.

REWELL, R.-E. (1948). - Diseases of tropical origin in captive wild animals. Tr. Roy. Soc. Trop. Med et Hyg. 42 (1), 17-25 (Helm. Abst. 17 (2), Abst. No. $134 \mathrm{~g}$ ).

Skrjabin K.-I., Shikhobalova N.-P., and Schults, R.-S., (1954). - Principles of Nematodology, Edited by K.-I. Skrjabin. Vol III. Trichostrongyloidea of animals and man, Moscow: Izdatelstvo Akademii Nauk SSSR, 683 pp. (In Russian): Trichostrongylids of animals and man. Essentials of Nematology, III. Academy of Sciences of U.S.S.R. (Translated from Russian. Israel Program for Scientific Translations 1960, 704 pp. 
SLOAN, J.-E.-N. (1951). - A note on the occurence of Trichostrongylus retortaeformis in the black buck (Antilope cervicapra). Proc. Zool. Soc. London, 121 (3) 723-725.

Southwell, T. (1930). - The fauna of British India including Ceylon and Burma. Cestoda. Vol. II. Taylor and Francis. London. 262 pp.

WARDLE, R.-A. and MCLEOD, J.-A. (1952). - The Zoology of tapeworms. The University of Minnosota Press, Minneapolis. 780 pp.

Yamaguti, S. (1959). - Systema helminthum. Vol. II. The Cestodes of Vertebrates. Interscience Publishers, Inc., New-York, London 860 pp.

Yeh, Liang SANg (1959). - A revision of the Nematode genus Setaria Viborg, 1795, its host-parasite relationship, speciation and evolution. J. Helminth. 33 (1), 1-98.

(Department of Parasitology, U.P. College of Veterinary Science and Animal Husbandry, Mathura, India). 